\title{
Factors influencing the characteristics of a good teacher with a degree in Management \& Accounting Course - Islamic Azad University Ghorveh
}

\author{
Morteza Ziaee \\ Department of Management, Ghorveh Branch, Islamic Azad University, Ghorveh, Iran \\ E-mail address: morteza_ziaee@yahoo.com
}

\begin{abstract}
Today, the most important factor that plays a role in educating students. Will be attending, so centers Education of their professors revealed the suitability of a set-up and evaluation of the performance of the teachers are accustomed to determine the quality of education improve. Economic and social sectors of the education system of each country and the plan are the macro level. International accounting education in the education system as a very important role in helping the economic development. This is among the most prominent role in developing countries. Scientific and technical developments in accounting from the rapid economic growth have created the need for the accountants in specialized fields, acquire the necessary skills. Such processing requires specialist expertise and training of skilled manpower and the training is effective and efficient that is commensurate with the environmental conditions With regard to economic development such as accounting education system seems to stem from the failure had. And therefore it is necessary to develop the talents and expertise to create. Identify barriers to growth factors and accounting education, the first requirement is to eliminate these deficiencies. Questionnaires related to the research hypotheses, distributed among management and accounting students. Population study in two undergraduate accounting students who are enrolled in a semester are 2014-2015 and their number reached 122. After collecting the questionnaire results had suggested that they are heading to training the new facilities will not be used for educational and academic background, degree requirements for management and accounting students is not. So can be said that the current education system is not efficient management and accounting undergraduate.
\end{abstract}

Keywords: Education; education system; Accounting; Management; Islamic Azad University

\section{INTRODUCTION}

Today, there is a mistaken belief that the individual scholar, teacher It is assumed. While such a claim is not always true Many professionals and experts in the art can not be taught, to achieve little success. Of course, the opposite can also The teacher may not necessarily be true of any investigator not skill. Therefore, a good teacher should have (B) the maximum number of characters to be able to gain a reputation the institution. I have all the features of the presence of the initials for a master is not possible and therefore the institution Their perceptions of their academic competence criteria of the votes. That Glover and Brvnyg believe that good teachers always Good model for their students' roles are How beneficial cooperation and bring it with others Teach and their teaching methods to the needs and Are coordinating their talents A 
fundamental tenet of the accounting profession is that accounting information is important for business decision making (McCarthy et al., 1982). In virtually all large companies accounting information is recorded, managed and often analysed in enterprise systems. Consequently we have witnessed an increase in the importance (and complexity) of enterprise systems and broadening in scope of the financial and non-financial information they provide. This shift evidences that "many of the traditional, essential skills of CPAs [professional accountants] are being replaced by new technologies that are increasing in number and being rapidly developed (AICPA, 1998: 3). Accordingly as accountants increasingly use these systems to support business decision making, they must be educated in the operation of technologically enabled business processes, including at the tertiary level.Enterprise systems provide support for managing business processes. Accountants need to understand these processes so they can understand the risks that are present and highlight the internal control problems. This creates a significant opportunity for the accounting profession to take a central role in the configuration and management of processes within an enterprise system (Arnold \& Sutton 2007). As a result it is no longer enough for graduates from the accounting profession to be narrow technical experts in financial or management accounting. Instead they must be able to relate their knowledge effectively to the broader business environment (Dunn \& McCarthy, 1997). Set of decisions and actions that are taken or done one after another and the aim of achieving the goal of education is more inclusive (Hemmatt Far and colleagues, 2010). Education and training in the dynamics of the continuing teaching and learning, intellectual engagement have always been thinkers. With various theories and discusses the causes of performance degradation and failure analysis and training system challenges in certain areas of science and studies on the structure and nature of human though processes, effective steps are taken to improve the education process. It is inferred that the scientific study of the history of science throughout history and drop in on how their training had leap and slump and if the current situation is desirable Thanks to efforts and causes weakness and shortcomings and to use effective methods of removing them Few thinkers and scholars in history, we know that this matter be addressedhow to improve science education at various stages throughout history, have gone through the steps overview of the law relating to improving education each discipline has been a member. Functions are also involved in professional societies, the emphasis on continuing professional education programs and training methods have improved. Emphasis on continuing education for professionals from the International Federation of Accountants (IFAC) and Article 14 of the Iranian Society of CPAs can be noted. In recent years Accounting Education Change Commission (AECC) with a critique of traditional methods to methods of accounting education has changed (by the oven and colleagues, 2010).

\section{THE EXPRESSION}

Economic and social sectors of the educational system of each country and the planning that is done at the macro level So that this system, in which a series of complex components and systems, is organized in such a way. Constant interaction between the predetermined learning objectives achieved. The system or systems, the data includes: learners, instructors, textbooks, space and equipment costs, etc. The educational process includes teaching, engaging learners and educators, learners interact with learners, etc. And finally the system output, changes are graduates (Etemadi, Hosein, 2009). The role of education in economic development, social and cultural communities of the past have been so obvious that it requires the development of any society that has developed in the education system. But the limited 
human and financial resource that the communities are faced with this issue is difficult. Therefore, education officials and planners to effectively (performance), the education system, special attention must be focused determine the effectiveness of the education system, is determined.

The resources available to the public education system has been used to how good way 1384. When the education system as a system considered to be natural with words such as input and output and employment have Since all the data, will not graduate. Response against foreign and domestic investment and attract investors 1992. How the formation and development of accounting majors in the twentieth century, the growth business units, business and state laws and tax regulations have been. The scientific and technical advances in this field and accelerated economic growth has created the need to Accountants in the areas of specialized skills necessary to obtain such processing requires specialist expertise and trained manpower, the training is effective and efficient. That is commensurate with the environmental conditions It seems that the economic transformation of education systems and incomplete accounting of the failures have And therefore it is necessary to develop the talents and expertise to create. Therefore in this study, we sought to answer these questions that do segment undergraduate accounting education in universities and higher education institutions in terms of syllabus and curriculum development, knowledge and skills taught masters courses in accounting, the use of modern educational facilities and scientific background of the students designed and planned. That decision makers are unable to meet financial needs and information?

\section{1. The importance of education in economic development}

Economic development, simply put, involves improving the physical environment and environmental objectives such as increasing per capita national income, fair distribution of wealth and material well-being of all people to be secure requires that the goals of increasing economic power reproductive scientists in the economy, factors of production include labor, raw materials and capital, and Believed to be much more productive use, economy stamina is stronger (and Jamshid Nejad, 1387). After World War II experience was that Injection material aid to save the Third World is not enough, and the lack of financial capital, barriers and other bottlenecks in the way of development are, for some scientists, such as the Sonilson, Ading and Alvin (1962), Harbinson and Myers (1964), to discover the bottlenecks and issues in comparative studies on their national development. Comparative studies, the world's attention to the role of education in economic life drew many scientists and economists to conclude that low levels of education; economic development is one of the major bottlenecks (Fauzat, 2003).

\section{1. 1. The importance of education in social development - political}

Community development - Political simple terms, involves the creation of solidarity and partnership interests, providing the freedom and sense of responsibility and justice, and social security. The association between educational systems as elite breeding, and selection of promising agents, with specific knowledge and insight into people and a great influence on the temperament and character of social and political bias, it can help to reduce the gap in.

\section{1. 2. Education of Accounting Practitioners}

Accounting practitioners have to keep current with developments in the areas of accounting, auditing and taxation to maintain their certification. Although local Ukrainian accounting firms provide some training, much of the IFRS training is provided by the Big-4 accounting firms. The reason for this preponderance of IFRS training is quite simple. It is 
mostly the Big-4 firms that have the expertise to conduct such training. They have excellent training materials, which have developed and evolved over several decades of trial and error and use. However, the training the Big-4 provides is not readily available to the local Ukrainian accounting community. Much of the training is limited to employees of the Big-4 and their clients. Furthermore, most of the training materials, for their employees at least, are available only in the English language.

That does not present a problem because the Big-4 only hires individuals who are fluent in English. In cases where course materials are used to train clients, some translation is done, but these materials generally are not made available to non-clients. There are some exceptions. For example, some of the Big-4 firms use training as a practice development tool. They hold some seminars and breakfast training sessions for potential clients. The training materials they distribute at these sessions are used not only for training but also to introduce potential clients to the quality of the training they offer, training that could be available to their employees if they became clients. The Big-4 firms provide ACCA, CPA and CFA training to their employees. One of the firms interviewed said it uses the Becker CPA Review materials. In the past it flew its staff to Moscow for training because there were no local training providers, but that situation has changed.

\section{THE CHALLENGES OF THE GLOBAL ENVIRONMENT}

Powerful economic and technological forces over the last few decades have forced national markets to expand beyond their borders seeking more capital resources than those locally available. Local governments and regulatory bodies have made this possible by adopting policies facilitating cross-border capital financing. Thus, the internationalization of capital markets, coupled with continuous attempts by major stock exchanges [New York, Tokyo, International (London), Frankfurt, Amsterdam, and Paris] to harmonize their listings and filing requirements, have created an urgent need for international dimensions in accounting education and practice.

In addition, increasing international trade of products, services, technology, and expertise, as well as growing foreign investment have become the driving forces of internationalization. As a result of these international business developments, the professional accounting, business, and financial communities have had to pay greater attention to international business activities. In response to the ever-changing international business environment, the Education Committee of the International Federation of Accountants (IFAC) released in June 1994 a Discussion Paper entitled "2000 and Beyond: A Strategic Framework for Prequalification Education in the Accounting Profession for the Year 2000 and Beyond" (IFAC, 1994). The traditional approach of including increasingly technical material was rejected by this committee in favor of a general approach focusing on learning to learn. Memorization of rules and regulations and the mere accumulation of knowledge should not be the goal of learning to learn. The latter emphasizes the need to understand both the underlying concepts and standards, and the ability to apply them and adapt them in a variety of situations. Learning to learn involves developing skills, knowledge, and professional orientation that help students learn more effectively, and to use these learning strategies to continue to learn throughout their lifetime as new knowledge and skills are required.

The Committee emphasized the need to develop accounting courses that focus on basic concepts and their application in real-world environments, and the relevant international and ethical issues. In response to more than two-thirds of accounting graduates choosing careers in 
the corporate world, the U.S. Institute of Management Accountants (IMA) and the U.S. Financial Executives Institute (FEI) commissioned a study that was published in 1994 on "What Corporate America Wants in Entry-Level Accountants." This study surveyed 2,700 corporate executives from a broad cross-section of industries and concluded that American universities are doing a less than adequate job of preparing students for entry-level work in management accounting. A joint IMA/FEI position statement issued at the 1994 American Accounting Association (AAA) Annual Meeting in New York concluded that "university accounting programs must be restructured to respond to the needs of the corporate customer." As cited earlier, the AICPA requirement for the new curriculum by the year 2001 is composed of at least 150 semester credit hours of general education (40\%), business administration (33\%), and accounting education $(27 \%)$. As to the general education requirement, the AICPA considered the importance of globalization as follows:

Our society is so intertwined with the rest of the world that an understanding of the multinational dimension is essential for the educated person. Included here are social, philosophical, political and environmental, as well as economic, issues. On the education in business administration, the AICPA stated the following:

Like business ethics, multinational issues should be part of the fabric of the various business disciplines. An awareness of our global economy is essential to understanding the business and accounting environment. Finally, on accounting education, the AICPA considered the following:

The international aspects of accounting should be addressed throughout the accounting portion of the curriculum. As is the case for the various business disciplines, an understanding of the impact of multinational business activity on accounting and on CPAs is necessary. The need for international dimensions in accounting education and practice was recognized by the AICPA in every one of three components of its proposed common body of knowledge for certified public accountants in the United States.

\section{OBJECTIVES OF EDUCATION FOR ACCOUNTANTS}

The purpose of this Statement is to set out the Commission's views on the objectives of Education for accountants. The Commission believes such a statement will provide a focus for those participating in the work of improving accounting education. The Commission's aim is to enlist the cooperation and creativity of the academic community and other stakeholders to bring about needed changes in accounting education.

The need for changes has arisen because accounting programs have not kept pace with the dynamic, complex, expanding, and constantly changing profession for which students are being educated. The need has been documented in "Future Accounting Education: Preparing for the Expanding Profession" (the Bedford Committee Report) and "Perspectives on Education: Capabilities for Success in the Accounting Profession". The Commission defines the accounting profession broadly. It includes career paths in public accounting as practice in large, medium, and small firms, corporate accounting (including financial management, controllership, treasury, financial analysis, planning and budgeting, cost accounting, internal audit, systems, tax, and general accounting), and government and nonprofit accounting. 


\section{1. Introduce some bias in the accounting field}

\section{General Business Education}

Professional accountants must understand the environments in which they work. Accounting programs should therefore include courses designed to develop knowledge of the functional activities of business, government, and nonprofit organizations. The courses should cover finance, marketing, operations, organizational behavior, and how the general manager integrates all these functions. The introductory accounting course should be given special attention. It must serve the interests of students who are not going to enter the profession as well as those who are. The broad approach recommended in these objectives serves the interests and needs of both groups. The course should teach, reinforce, and reward the skills, abilities, and attitudes that are necessary for success in the accounting profession. This will give students accurate knowledge about the nature of accounting careers, which will help them make a well informed choice about entering the profession.

\section{General Accounting Education}

Accounting courses should present accounting as an information development and communication process. The central theme should be how information is identified, measured, communicated, and used. The courses' essential components should be: 1) decision making and information in organizations, 2) design and use of information systems, 3) financial information and public reporting including attestation, and 4) knowledge of the accounting profession. Courses should focus on both basic concepts and the application of these concepts in real-world environments, including international and ethical issues.

\section{Specialized Accounting Education}

Specialized accounting education should follow only after attainment of general accounting, organizational, and business knowledge. Therefore, it should be offered primarily at the post-baccalaureate level and via continuing education. Specialized accounting programs may include advanced study in financial accounting, management accounting, taxation, information systems, auditing, government (or nonprofit) accounting, and international accounting. Continuing professional education may overlap considerably with specialized accounting education offered by universities. The principle of comparative advantage should govern which types of specializations are offered by universities and which by others.

\section{Financial Accounting}

Financial Accounting (ACCT 2101), an introductory financial accounting principles course, is a required course for all business majors. Other majors that require this course include International Trade, a University Program offered by the Center for International Studies, and Business Education within the College of Education. Within the Allen E. Paulson College of Science and Technology, Printing Management majors may elect to take this as part of a minor in business. Financial Accounting is designed to acquaint students with basic financial accounting concepts and to demonstrate how generally accepted accounting principles are applied in the business environment. The course presents the rules of debits and credits and guides students through the accounting cycle - from transaction to financial statements. After completion of the accounting cycle, each individual financial statement component (Assets, Liabilities, Equity, Revenues and Expenses) is reviewed in more detail,including the different 
methods of accounting for each and how a company's choice of accounting principle can impact cash flows and taxes

\section{Managerial Accounting}

Managerial Accounting (ACCT 2102), an introductory managerial accounting principles course, is required for all business majors. As with Financial Accounting, other majors that require this course include International Trade and Business Education. Printing Management majors may elect to take this as part of a minor in business. Managerial Accounting demonstrates how managers and other business people use accounting information to make more informed decisions. The course focuses on the major themes in managerial accounting including basic cost concepts and classifications, cost accumulation systems, product costs, budget preparation (operating, financial and capital), performance evaluation, cost behavior, cost volume profit analysis, and variance analysis. The course also explores the concepts of total quality management and quality cost control. Students gain an understanding of how accounting is an integral part of the other management functions.

\section{RESEARCH METHOD}

This study describes and analyzes the viewpoints of accounting students at the Azad University Ghorveh. The method is a descriptive correlative study because the views and opinions of Azad University in Ghorveh executives in connection with the research variables and their relations are measured. Statistical population of research include accounting students at the Azad University in Ghorveh in semestre (2013) Totaled 122.

\section{1. Analysis Result}

H0: Tire transition coefficients having good morals can not be a good teacher.

$\mathrm{H} 1$ : Coefficients of transitioning to a tire having good manners can be a good teacher.

Table 1. The first hypothesis test.

\begin{tabular}{|c|c|c|c|}
\hline T Calculated & T Schedule & Significant & Test \\
\hline $13 / 23$ & $1 / 645$ & $0 / 05$ & $\begin{array}{c}\text { Confirm the } \\
\text { hypothesis }\end{array}$ \\
\hline
\end{tabular}

Conclusion: Because the test criteria were used in the critical region, with a confidence level of $95 \%$ is accepted. In other words, rejection and H1 first research hypothesis is confirmed.

H0: Master of Science Information can not be influenced to choose a good master of his Teachers.

H1: Science teacher can influence the choice of his good teacher Are. 
Table 2. The second hypothesis test.

\begin{tabular}{|c|c|c|c|}
\hline T Calculated & T Schedule & Significant & Test \\
\hline $19 / 18$ & $1 / 645$ & $0 / 05$ & $\begin{array}{c}\text { Confirm the } \\
\text { hypothesis }\end{array}$ \\
\hline
\end{tabular}

Conclusion: Because the test criteria were used in the critical region, with a confidence level of $95 \%$ is accepted. In other words, $\mathrm{H} 0$ hypothesis is rejected and the Far $1 \mathrm{H}$ II study are confirmed..

H0: Research Information for teachers not pick him as a good teacher can help.

H1: Research Information for teachers Mtvand to help her pick a good teacher.

Table 3. The third hypothesis test.

\begin{tabular}{|c|c|c|c|}
\hline T Calculated & T Schedule & Significant & Test \\
\hline $13 / 30$ & $1 / 645$ & $0 / 05$ & $\begin{array}{c}\text { Confirm the } \\
\text { hypothesis }\end{array}$ \\
\hline
\end{tabular}

Conclusion: Because the test criteria were used in the critical region, with a confidence level of $5 \%$ is accepted. In other words, reject $\mathrm{H} 0$ and 1 third hypothesis is confirmed by research.

\section{DISCUSSION AND CONCLUSION}

Evaluation of faculty members at each institution One of the most notable programs is the provision and development evaluation of an institution's top priorities of a good teacher Education is considered. Than the other side of technology Teacher training and most important success factor for achieving Educational goals are. Most commonly methods for determining the suitability of a good teacher survey Students. Studies during the past Numerous measures in this regard to a professor. The students are well determined. Familiarity with a view. We help clients to educate students as the main characteristics of the valve to be a good teacher Students meet with the appropriate program activities. Teaching and assessment, we can make an informed decision. In our study the characteristics of a good teacher and a good degree in accounting were divided into three categories: The first category features a professor, Division II and Division III Professor of Information Science Research in the field of information material is Professor of Education and Science. According to the test results and statistical analysis showed that students in terms of accounting. These three features can help other researchers. 


\section{References}

[1] Albrecht S., Sack R., The perilous future of Accounting Education, The CPA Journal 71 (2001) 16-23.

[2] American Accounting Association (AAA). Committee on the future structer content and scope of education future accounting education, preparing for expanding profession, Journal of Accounting Education, 1986, 168-190.

[3] Brown S. A, Harrist R. B., Villagomez E. T., Segura M., Barton S. A., Hanis C. L., Gender and treatment differences in knowledge, health beliefs, and metabolic control in Mexican Americans with type 2 diabetes. Diabetes Educ., 2000, 25-38.

[4] Edward J. Sullivan, Teaching Financial Statement Analysis:a cooperative Learning Approach, Journal of Accounting Education 14 (1996) 63-95.

[5] Funnell M. M., et al., National standards for diabetes self-management education. Diabetes Care, 2008, 97-104.

[6] Gordon Boycc, Critical accounting education: Teaching and Learning outside the circle. Journal of critical perspectives on accounting 15 (2004) 565-586.

[7] Konh Hian Chye, Konh, Moy Yin, Empirical Evaluation of Accounting programs: A proposed factor analytic approach, Journal of Accounting Education, 1998, 295-314.

[8] Mohamed E. K. A., Lashine S. H., Accounting knowledge and skills and the challenges of a global business environment, Journal of Accounting Education 42 (2003) 3-17.

[9] Robbins J. M., Thatcher G. E., Webb D. A., Valdmanis V. G., Nutritionist visits, diabetes classes, and hospitalization rates and charges: the Urban Diabetes Study Diabetes Care, 2008, 655-660.

[10] Sicgels \& Sorenson, What corporate America wants in entry level accountants? Journal of management accounting, 1994, 3-12. 